\title{
Growth hormone alters lipid composition and increases the abundance of casein and lactalbumin mRNA in the MAC-T cell line
}

\author{
Tasha L Johnson ${ }^{1}$, Brent AS Fujimoto ${ }^{1}$, Rafaél Jiménez-Flores ${ }^{2}$ and Daniel G Peterson ${ }^{1}{ }^{*}$ \\ ${ }^{1}$ Animal Science Department and \\ ${ }^{2}$ Dairy Science Department, California Polytechnic State University, San Luis Obispo 93407
}

Received 27 May 2009; accepted for publication 11 November 2009

\begin{abstract}
The MAC-T cell line has been used extensively to investigate bovine mammary epithelial cell function. A lactogenic phenotype is generally induced in this cell line by a combination of dexamethasone, insulin and prolactin and has typically been assessed by milk protein production. Few studies have focused on identifying other factors that may affect milk protein synthesis in the MAC-T cell line, and none have considered the lipid class distribution of MAC-T cells as a component of the lactogenic phenotype. Growth hormone $(\mathrm{GH})$ has been shown to increase milk protein synthesis both in vivo and in mammary cell models, and has been shown to alter the lipogenic profile of mammary explant models. We tested the hypothesis that MAC-T cells would respond directly to $\mathrm{GH}$ and that the response would include alterations to the lipid class distribution as well as to milk protein gene expression, leading to a more appropriate model for mammary cell function than treatment with dexamethasone, insulin and prolactin alone. Differentiated cells expressed $\mathrm{GH}$ receptor mRNA, and addition of $\mathrm{GH}$ to the differentiation medium significantly induced production of $\alpha_{-s 1}$ casein and $\alpha$-lactalbumin mRNA. GH also significantly affected the proportion of triacylglycerol and sphingomyelin. These results indicate that $\mathrm{GH}$ is an important factor in inducing a lactogenic phenotype in the MAC-T cell line, and support the possibility of a direct effect of $\mathrm{GH}$ on milk synthesis in vivo.
\end{abstract}

Keywords: Growth hormone, somatotropin, MAC-T, mammary, lipid, milk protein.

The mammary epithelial cell is responsible for the synthesis and secretion of milk components and therefore is a primary focus for the study of mammary function. The mammary alveolar cell-T (MAC-T) is a continuous cell line derived from bovine mammary tissue by stable transfection with the SV-40 large T-antigen (Huynh, 1991) and has been used extensively for the study of mammary epithelial cell function. Induction and maintenance of a lactogenic phenotype in mammary cell and explant models, including the MAC-T cell line, has commonly been achieved using a combination of dexamethasone, insulin and prolactin (PRL; e.g. Huynh, 1991; Matitashvili, 1997).

Growth hormone $(\mathrm{GH})$, also termed somatotropin, is known to have stimulatory effects on milk production in vivo (reviewed by Bauman, 1992; Bauman \& Vernon, 1993; Bauman, 1999) and while it is well accepted that $\mathrm{GH}$ acts through somatomedins such as the insulin-like

*For correspondence; e-mail: dpeterso@calpoly.edu growth factors produced locally and by the liver, it remains somewhat in question whether the effects of $\mathrm{GH}$ include direct influence on the mammary epithelium (e.g. see Bauman \& Vernon, 1993; Svennersten-Sjaunja \& Olson, 2005; Akers, 2006). GH receptor (GHR) has been detected in mammary tissue (e.g. Hauser et al. 1990; Plath-Gabler et al. 2001) and investigation into the effects of $\mathrm{GH}$ administration on the mammary epithelium in particular have subsequently been pursued in cell models of lactation. Sakamoto et al. (2005) observed GHR expression on the surface of a novel bovine mammary cell line cloned from a Holstein heifer, and found that $\mathrm{GH}$ administration to these cells enhanced their secretion of $\alpha$-casein both independently and in synergy with the classical combination of dexamethasone, insulin and PRL (DIP). Additionally, these investigators noted that treatment with DIP but without $\mathrm{GH}$ enhanced the expression of GHR in the mammary cells. More recently, both the GHR and the signal transducer and activator of transcription 5 (STAT5) were ectopically expressed in MAC-T cells, and 
Table 1. Primer sequences used for quantitative PCR analysis in this study

$\begin{array}{ll}\text { Target } & \text { Sense Primer }\left(5^{\prime}-3^{\prime}\right) \\ \text { GHR } & \text { CTAACTAGCAATGGCGGT } \\ \text { LALBA } & \text { AAAGACGACCAGAACCCTCA } \\ \text { CSN1S1 } & \text { AATCCATGCCCAACAGAAAG } \\ \text { ACTB } & \text { GCGTGGCTACAGCTTCACC }\end{array}$

Antisense Primer $\left(5^{\prime}-3^{\prime}\right)$
GGGTGGATCTGGTTGTACTA
GCTTTATGGGCCAACCAGTA
TCAGAGCCAATGGGATTAGG
TTGATGTCACGGACGATTTC

Sourcet

NM_176608

Zhou et al. 2008

Zhou et al. 2008

Bionaz \& Loor, 2007

+ GHR primers were designed from GenBank accession number NM_176608 using PrimerQuest software available at www.idtdna.com and primer quality was further assessed using Beacon Designer (Premier Biosoft International)

subsequent treatment with $\mathrm{GH}$ led to significant increases in the abundance of $\alpha_{\mathrm{s}^{-}}, \alpha_{\mathrm{s} 2^{-}}$and $\beta$-casein, as well as $\alpha$-lactalbumin mRNA (Zhou et al. 2008). While these investigators were able to detect GHR mRNA in MAC-T cells both by PCR and ribonuclease protection assay, the overexpression of GHR and STAT5 was intended to exaggerate any response to $\mathrm{GH}$ that may have been observed; no data were reported on the effects of $\mathrm{GH}$ in the untransfected cells.

The influence of lactogenic hormones on milk protein production is an important means of assessing the quality of a mammary cell model, though the lipogenic profile of mammary cells could also be used to determine the pertinence of such a model. Milk lipids consist mainly of triacylglycerol (TAG) and while freshly dispersed mammary cells of ruminant origin synthesize predominanty TAG (Hansen \& Knudsen, 1987a,b) the MAC-T cell line produces predominantly polar lipids under the traditional lactogenic hormone milieu (present work and D G Peterson, unpublished observations). Treatments that increase the proportion of TAG synthesized by cultured mammary cells could be useful, particularly when studying mammary lipogenesis.

The recent findings with respect to $\mathrm{GH}$ treatment of mammary cell lines led us to the hypothesis that $\mathrm{GH}$ may act directly to alter milk protein synthesis and the lipid class distribution of MAC-T cells to better mimic the mammary epithelium in vivo. Our objectives were to determine whether the cells expressed GHR mRNA, and whether the addition of $\mathrm{GH}$ to the differentiation medium would affect the abundance of $\alpha$-lactalbumin and $\alpha{ }_{s 1}$-casein mRNA, as well as the lipid class distribution as determined by thin-layer chromatography.

\section{Materials and Methods}

All reagents were acquired from Sigma Aldrich (St Louis $\mathrm{MO}$, USA) unless otherwise stated.

\section{Cell culture and treatments}

MAC-T cells were grown to confluence in 100-mm diameter CellBIND-treated plastic cell culture dishes (Corning Inc., Corning NY, USA) using a proliferation medium consisting of Dulbecco's Modified Eagle's Medium (DMEM), $10 \%$ fetal bovine serum (FBS; Innovative
Research, Novi MI, USA), $1 \%$ penicillin/streptomycin, $5 \mu \mathrm{g} / \mathrm{ml}$ insulin, $1 \mu \mathrm{g} / \mathrm{ml}$ progesterone. To ensure that any effect of serum was consistent between treatments, all FBS used was from a single lot. Once confluent, MAC-T cells were treated for $7 \mathrm{~d}$ with differentiation medium consisting of DMEM, $10 \%$ FBS, $1 \%$ penicillin/streptomycin, $10 \mu \mathrm{g} / \mathrm{ml}$ dexamethasone, $5 \mu \mathrm{g} / \mathrm{ml}$ insulin, $5 \mu \mathrm{g} / \mathrm{ml}$ prolactin and either 0 or $10 \mathrm{ng} / \mathrm{ml}$ bovine $\mathrm{GH}$ [generously provided by G Bogosian (gregg.bogosian@monsanto.com) at Monsanto, St. Louis MO, USA]. Each experiment was conducted in triplicate.

\section{mRNA abundance}

For determination of mRNA abundance, cells were harvested from one confluent $100-\mathrm{mm}$ plate per replicate ( $n=3$ replicates) by scraping, total RNA was extracted using the RNeasy kit (Qiagen, Valencia CA, USA) and $500 \mathrm{ng}$ was reverse transcribed using oligo dT primed iScript Select cDNA synthesis kit (Bio-Rad Laboratories, Hercules CA, USA). Abundance of GHR, $\alpha$-lactalbumin (LALBA) and $\alpha_{\mathrm{s} 1}$-casein (CSN1S1) mRNA was determined by quantitative PCR using Fast SYBR Green Master Mix (Applied Biosystems, Foster City CA, USA) and the primers specified in Table 1. All primers were obtained from Integrated DNA Technologies (Coralville IA, USA). Reactions were carried out using a 7500Fast PCR system (Applied Biosystems) with an initial denaturing step of $20 \mathrm{~s}$ at $95{ }^{\circ} \mathrm{C}$ followed by 55 cycles of $3 \mathrm{~s}$ at $95{ }^{\circ} \mathrm{C}$ and $30 \mathrm{~s}$ at $60^{\circ} \mathrm{C}$. Initial target mRNA abundance was calculated using the $2^{-\Delta \Delta C t}$ method with abundance of $\beta$-actin mRNA serving as an internal control to correct for the efficiency of reverse transcription and data for each treatment were expressed relative to the undifferentiated cells (Livak \& Schmittgen, 2001). PCR product quality and specificity were verified by melt curve analysis and subsequent agarose gel electrophoresis.

\section{Lipid composition}

For lipid separation, cells were harvested by scraping from two confluent $100-\mathrm{mm}$ plates of cells per replicate ( $n=3$ replicates) and subsequently pelleted by centrifugation at $500 \mathrm{~g}$ at $4{ }^{\circ} \mathrm{C}$ for $10 \mathrm{~min}$. Total lipid was extracted from the cell pellet using 2:1 chloroform-methanol (Folch et al. 1957) and separated on the basis of polarity by thin layer chromatography (TLC) using a 65:25:4 
chloroform-methanol-water mobile phase (Christie, 1982). TLC plates were placed in a sealed chamber with iodine crystals for $24 \mathrm{~h}$ followed immediately by scanning and quantification by densitometry using Molecular Analyst (Bio Rad, Hercules CA, USA). Relative abundance was calculated as the density of each band normalized to the total density of all bands for each lane on each TLC plate. Bands were identified by comparison with standards representing TAG, cholesterol, phosphatidylethanolamine (PE), phosphatidylcholine (PC), phosphatidylinositol (PI) and sphingomyelin (SM) that were included with each plate; two bands did not correspond to any of the chosen standards and are designated Unknown.

\section{Cell viability}

Cell viability was assessed in parallel cultures grown as described above. Viability was assessed in cells grown to confluence in proliferation medium, as well as in cells differentiated with DIP alone and DIP+10 ng/ml GH using flow cytometry with the ViaCount cell viability assay (Guava Technologies, Hayward CA, USA) according to the manufacturer's recommendation in a Guava EasyCyte Plus flow cytometer (Guava Technologies). Prior to incubation with the ViaCount reagent, cells were detached from the culture substrate by incubation with trypsin-EDTA solution and washed in complete medium before pelleting and resuspension in PBS.

\section{Statistical analysis}

Lipid composition data were analysed using the general linear model of SAS (SAS Institute, Cary NC, USA) for differences between treatments. Data were transformed by arcsine-square root for analysis owing to a tendency for non-normality at the extremes of values represented as a proportion (between 0 and 1; Freeman \& Tukey, 1950). Pairwise comparisons between means were made using the Tukey test. For statistical analysis of mRNA abundance and cell viability data, normalized abundance for each treatment was analysed using the general linear model of SAS for differences between treatments. Tukey's simultaneous test was used to compare all means with each other. In all cases, differences were considered significant at $P<0 \cdot 05$.

\section{Results}

To determine whether any effect of $\mathrm{GH}$ could be due to direct, receptor-mediated effects, we used the classical DIP differentiation protocol with either 0 or $10 \mathrm{ng} / \mathrm{ml} \mathrm{GH}$ and quantified the abundance of GHR mRNA, as well as that of two milk protein genes, LALBA and CSN1S1. Differentiation with DIP in the absence of $\mathrm{GH}$ led to a 14-fold increase in GHR mRNA, while DIP with $10 \mathrm{ng} / \mathrm{ml}$ $\mathrm{GH}$ led to a 35-fold increase in GHR mRNA compared with the undifferentiated cells (Fig. 1A). Differentiation
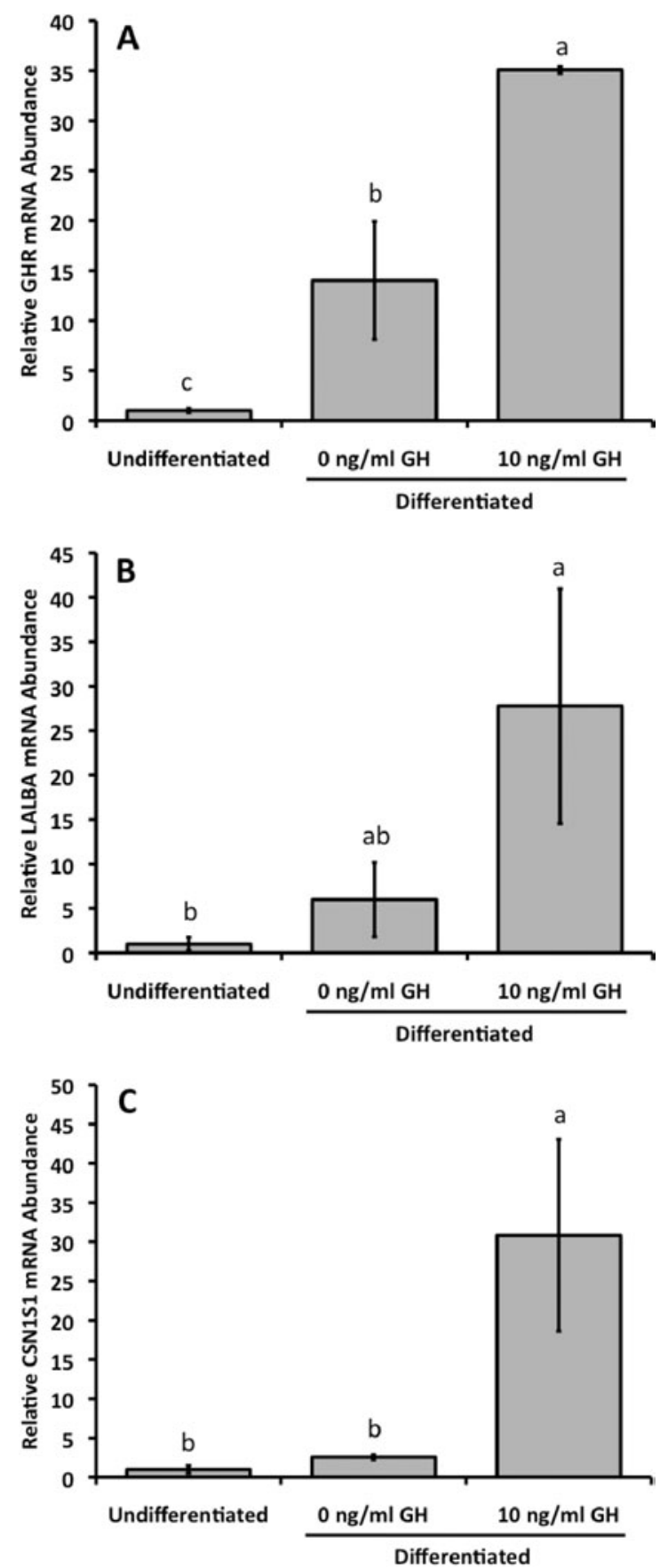

Fig. 1. Abundance of growth hormone receptor (GHR; panel $A)$, $\propto$-lactalbumin (LALBA; panel B) and $\propto_{\mathrm{s} 1}$-casein (CSN1S1; panel C) mRNA in undifferentiated MAC-T cells as well as those differentiated with either 0 or $10 \mathrm{ng} / \mathrm{ml} \mathrm{GH}$. Undifferentiated cells were grown to confluence in DMEM supplemented with $10 \% \mathrm{FBS}, 5 \mu \mathrm{g} / \mathrm{ml}$ insulin and $1 \mu \mathrm{g} / \mathrm{ml}$ progesterone; differentiated cells were grown to confluence as the undifferentiated cells then cultured for $7 \mathrm{~d}$ in DMEM supplemented with $10 \%$ FBS, $5 \mu \mathrm{g} / \mathrm{ml}$ insulin, $10 \mu \mathrm{g} / \mathrm{ml}$ dexamethasone, $5 \mu \mathrm{g} / \mathrm{ml} \mathrm{PRL}$, and the $\mathrm{GH}$ concentrations noted. Relative mRNA abundance was assessed by quantitative PCR and normalized to the expression of $\beta$-actin. Values represented are means $(n=3)$; error bars represent SEM; values without a common letter differ $(P<0 \cdot 05)$. 
Table 2. Lipid class distribution of MAC-T cells grown to confluence in DMEM supplemented with $10 \%$ FBS, $5 \mu \mathrm{g} / \mathrm{ml}$ insulin and $1 \mu \mathrm{g} / \mathrm{ml}$ progesterone, and then differentiated for $7 \mathrm{~d}$ in DMEM supplemented with $10 \% \mathrm{FBS}, 5 \mu \mathrm{g} / \mathrm{ml}$ insulin, $10 \mu \mathrm{g} / \mathrm{ml}$ dexamethasone and either 0 or $10 \mathrm{ng} / \mathrm{ml} \mathrm{GH}$. Values are means $(n=3)$ with SEM, the pooled standard error of the mean for each dependent variable

\begin{tabular}{|c|c|c|c|}
\hline & & ml) & \\
\hline & 0 & 10 & $P$ \\
\hline Triacylglycerol & $10 \cdot 3 \pm 1 \cdot 0$ & $18 \cdot 6 \pm 0 \cdot 2$ & $<0 \cdot 01$ \\
\hline Cholesterol & $18 \cdot 8 \pm 1 \cdot 7$ & $24 \cdot 5 \pm 5 \cdot 9$ & $0 \cdot 16$ \\
\hline Phosphatidylethanolamine & $7 \cdot 0 \pm 0 \cdot 6$ & $6 \cdot 7 \pm 0 \cdot 7$ & $0 \cdot 80$ \\
\hline Phosphatidylcholine+phosphatidylinositolt & $7 \cdot 3 \pm 0 \cdot 3$ & $6 \cdot 0 \pm 0 \cdot 4$ & 0.07 \\
\hline Sphingomyelin $1 \neq$ & $24 \cdot 3 \pm 2 \cdot 2$ & $24 \cdot 6 \pm 1 \cdot 7$ & 0.92 \\
\hline Sphingomyelin $2 \ddagger$ & $13 \cdot 4 \pm 0 \cdot 3$ & $3 \cdot 7 \pm 0 \cdot 4$ & $<0.01$ \\
\hline Unknown $1 \S$ & $4 \cdot 2 \pm 0 \cdot 4$ & $2 \cdot 8 \pm 0 \cdot 6$ & $0 \cdot 13$ \\
\hline Unknown $2 \S$ & $9 \cdot 6 \pm 1 \cdot 7$ & $7 \cdot 2 \pm 1 \cdot 8$ & $0 \cdot 39$ \\
\hline Origin & $5 \cdot 3 \pm 0 \cdot 9$ & $6 \cdot 0 \pm 1 \cdot 0$ & 0.66 \\
\hline
\end{tabular}

† Co-eluted and are expressed as the combined value

₹ Spingomyelin eluted as two separate bands as has been previously observed (Ramstedt et al. 1999) and each band is represented individually $\S$ Two bands did not correspond to any of the chosen standards, and are represented as Unknown

with DIP led to small numerical increases in LALBA and CSN1S1 mRNA that were not significant, while GH addition to the differentiation media led to significant 28- and 32-fold increases in LALBA and CSN1S1 mRNA, respectively, as compared with the undifferentiated controls (Figs 1B, C).

Observations of our TLC plates indicate that PC and PI migrated as one band with the current protocol, and SM eluted as two separate bands as has been described previously (Ramstedt et al. 1999). Semi-quantitative analysis of lipid class distribution was achieved by densitometry and the results are shown in Table 2. Differentiation with $10 \mathrm{ng} / \mathrm{ml} \mathrm{GH}$ led to an $80 \%$ increase in the proportion of TAG and a more than three-fold decrease in the proportion of the SM2 fraction $(P<0 \cdot 05)$. It is noteworthy that $10-14 \%$ of the total lipid did not correspond to any of our chosen standards (designated Unknown) and while these fractions were not significantly affected by $\mathrm{GH}$, it would be of interest to identify these lipid classes. Based on their migration in relation to the known lipid classes, these are polar lipids with Unknown 1 being more polar than SM, while Unknown 2 had a polarity in between SM and the $\mathrm{PC}+\mathrm{Pl}$ fraction.

To ensure that any differences observed were not due to differences in cell number due to $\mathrm{GH}$ addition to the differentiation media, we analysed cell viability and found no significant effect of $\mathrm{GH}$ on viable cell number or percent viable cells $(P>0 \cdot 20$; data not shown).

\section{Discussion}

There has been much speculation about the exact nature of the effects of $\mathrm{GH}$ on lactation in vivo, and it remains unclear whether $\mathrm{GH}$ has any direct effect on the mammary epithelium. The identification of GHR expression both in the bovine mammary gland (Plath-Gabler et al. 2001) and in bovine mammary cell lines including the MAC-T

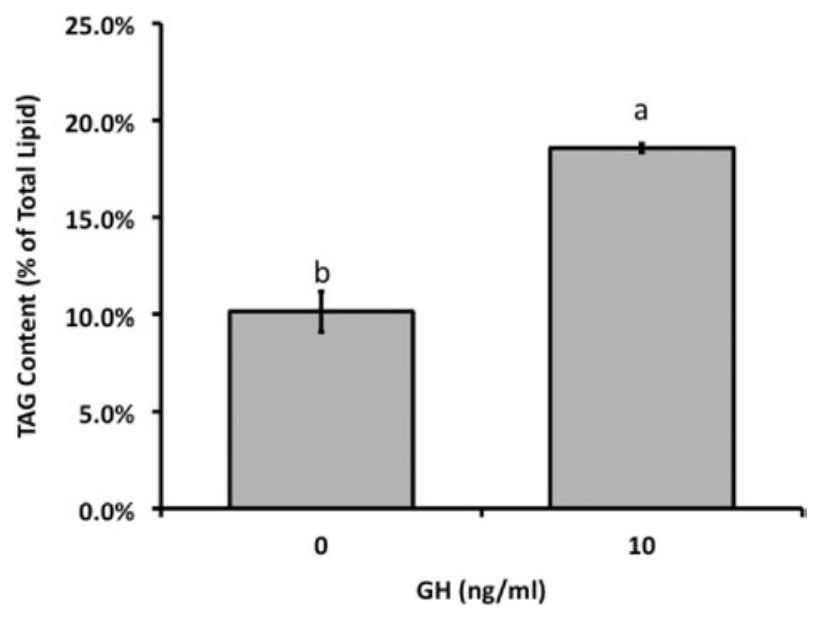

Fig. 2. Effect of growth hormone $(\mathrm{GH})$ on triacylglycerol (TAG) content in MAC-T cells. Cells were grown to confluence in DMEM supplemented with $10 \% \mathrm{FBS}, 5 \mu \mathrm{g} / \mathrm{ml}$ insulin and $1 \mu \mathrm{g} /$ $\mathrm{ml}$ progesterone, and then differentiated for $7 \mathrm{~d}$ in DMEM supplemented with $10 \%$ FBS, $5 \mu \mathrm{g} / \mathrm{ml}$ insulin, $10 \mu \mathrm{g} / \mathrm{ml}$ dexamethasone and either 0 or $10 \mathrm{ng} / \mathrm{ml} \mathrm{GH}$. Total lipids were extracted and lipid classes separated by TLC. Each band resulting from the TLC separation was quantified by densitometry and TAG content was calculated as a percent of the sum of all band densities for that lane. Values represented are means $(n=3)$; error bars represent SEM; values with different letters differ $(P<0 \cdot 01)$.

(Sakamoto et al. 2005; Zhou et al. 2008) indicate a possible direct influence of $\mathrm{GH}$ on the mammary epithelial cell. Accordingly, Sakamoto et al. (2005) showed a positive influence of $\mathrm{GH}$ on milk protein production in a mammary cell line. More recently, Zhou et al. (2008) demonstrated that $\mathrm{GH}$ administered to MAC-T cells that were overexpressing GHR and STAT5 also led to increased production of milk proteins. 
The demonstration of very low GHR abundance in undifferentiated native MAC-T cells by Zhou et al. (2008) led us to determine the abundance of GHR mRNA in undifferentiated cells as well as those differentiated with either DIP or DIP and GH. We found that differentiation led to a significant increase in the abundance of GHR mRNA, and that this was even more dramatic in the $\mathrm{GH}$ treated cells. A similar pattern was observed for two major milk protein genes, CSN1S1 and LALBA, though it was surprising to find a much greater difference between the DIP differentiated cells with and without GH than between undifferentiated cells and those differentiated with DIP alone.

The lipid component of milk represents the major energy cost for milk production, the primary energy source for the consumer of whole milk, and a natural source of bioactive compounds such as conjugated linoleic acids. As such, milk fat synthesis is of interest to many research groups, and a convenient cell model for the study of milk fat synthesis would be of great value. While Hansen \& Knudsen $(1987 a, b)$ have reported that freshly dispersed mammary cells of bovine and caprine origin predominantly produce TAG, the major lipid class of secreted milk fat, there is no report of the actual secretion of a milk fat globule by a mammary cell model. Fekry et al. (1989) found that milk lipid synthesis was enhanced in bovine mammary explants treated with $\mathrm{GH}$, though only when co-cultured with adipose and liver explants, leading to the conclusion that the effects of $\mathrm{GH}$ on mammary lipid synthesis were indirect, possibly through IGF production by the liver explants.

Here, we have demonstrated that the addition of $\mathrm{GH}$ to differentiation medium shifts the lipid class distribution of MAC-T cells toward greater TAG content, a phenotype that more closely resembles lactation in vivo, and that this effect was observed without overexpression of GHR or STAT5. It is unclear from this experiment whether the change in TAG content as a proportion of total lipid represented an increase in actual amount of lipid synthesized. Our results indicate that changes in cell number due to proliferative or toxic effects of $\mathrm{GH}$ are not responsible for the alterations in lipid composition. Observations in vivo of increased output of milk with normal composition without any change in mammary DNA content indicate that $\mathrm{GH}$ acts to increase the overall synthetic capacity of the mammary gland (reviewed in Bauman, 1999). This overall change, whether direct, indirect, or both, would require a coordinated response within the cell that involved many different pathways, and our results demonstrate that $\mathrm{GH}$ affects not only lipid metabolism but also the mRNA abundance of two milk proteins in MAC-T cells. It is important to note that based on our analysis, the changes in mRNA abundance cannot be attributed specifically to increases in synthetic rate, but may instead represent changes in the stability of mRNA without any change in transcription rates.
The present results indicate that $\mathrm{GH}$ can directly affect the MAC-T cell line, and based on the presence and inducibility of GHR mRNA, that the effects of $\mathrm{GH}$ are likely mediated by GHR. Further, it appears that the effects of $\mathrm{GH}$ involve responses in milk protein mRNA abundance as well as lipogenic pathways, consistent with findings of $\mathrm{GH}$ treatment of lactating cows (reviewed by Bauman, 1999). It is possible that $\mathrm{GH}$ is important in attaining a more differentiated state in the MAC-T cells as opposed to enhancing the production of already differentiated cells. Either way, in developing cell culture models of lactation, it may be important to consider $\mathrm{GH}$ as an integral part of the hormone milieu that is required for maximal galactopoietic potential. Finally, these results support the developing hypothesis that $\mathrm{GH}$ may have a direct effect on mammary metabolism in vivo.

The authors would like to thank Dr Gregg Bogosian (Monsanto Co.) for providing the bST used in this project and Dr Matthew Burd, Dr Brooke Humphrey and Lisa McDonnell for critical review of the manuscript and technical assistance. Partial funding for this project was provided by the Department of the Navy, Office of Naval Research under award number N00014-06-11111 , and by the California State University Agricultural Research Initiative (ARI) under award number 07-3-011.

\section{References}

Akers RM 2006 Major advances associated with hormone and growth factor regulation of mammary growth and lactation in dairy cows. Journal of Dairy Science 89 1222-1234

Bauman DE 1992 Bovine somatotropin: review of an emerging animal technology. Journal of Dairy Science 75 3432-3451

Bauman DE 1999 Bovine somatotropin and lactation: from basic science to commercial application. Domestic Animal Endocrinology 17 101-116

Bauman DE \& Vernon RG 1993 Effects of exogenous bovine somatotropin on lactation. Annual Review of Nutrition 13 437-461

Bionaz M \& Loor JJ 2007 Identification of reference genes for quantitative real-time PCR in the bovine mammary gland during the lactation cycle. Physiological Genomics 29 312-319

Christie WW 1982 Lipid analysis: Isolation, Separation, Identification and Structural Analysis of Lipids. 2nd Edition. Oxford, Oxfordshire, England; New York NY, USA: Pergamon Press

Fekry AE, Keys JE, Capuco AV, Bitman J, Wood DL \& Miller RH 1989 Effect of bovine growth hormone on incorporation of [14C] acetate into lipids by co-cultures of bovine mammary, liver, and adipose tissue explants. Domestic Animal Endocrinology 6 87-94

Folch J, Lees M \& Sloane Stanley GH 1957 A simple method for the isolation and purification of total lipides from animal tissues. Journal of Biological Chemistry 226 497-509

Freeman MF \& Tukey JW 1950 Transformations related to the angular and the square root. The Annals of Mathematical Statistics 21 607-611

Hansen HO \& Knudsen J 1987a Effect of exogenous long-chain fatty acids on individual fatty acid synthesis by dispersed ruminant mammary gland cells. Journal of Dairy Science 70 1350-1354

Hansen HO \& Knudsen J 1987b Effect of exogenous long-chain fatty acids on lipid biosynthesis in dispersed ruminant mammary gland epithelial cells: esterification of long-chain exogenous fatty acids. Journal of Dairy Science 70 1344-1349

Hauser SD, McGrath MF, Collier RJ \& Krivi GG 1990 Cloning and in vivo expression of bovine growth hormone receptor mRNA. Molecular and Cellular Endocrinology 72 187-200 
Huynh HT, Robitaille G \& Turner JD 1991 Establishment of bovine mammary epithelial cells (MAC-T): An in vitro model for bovine lactation. Experimental Cell Research 197b 191-197

Livak KJ \& Schmittgen TD 2001 Analysis of relative gene expression data using real-time quantitative PCR and the $2_{\mathrm{T}}^{-\Delta \Delta C}$ method. Methods 25 402-408

Matitashvili E, Bramley AJ \& Zavizion B 1997 An in vitro approach to ruminant mammary gland biology. Biotechnology Advances $\mathbf{1 5}$ $17-40$

Plath-Gabler A, Gabler C, Sinowatz F, Berisha B \& Schams D 2001 The expression of the IGF family and GH receptor in the bovine mammary gland. Journal of Endocrinology 168 39-48
Ramstedt B, Leppimaki P, Axberg M \& Slotte JP 1999 Analysis of natural and synthetic sphingomyelins using high-performance thin-layer chromatography. European Journal of Biochemistry 266 997-1002

Sakamoto K, Komatsu T, Kobayashi T, Rose MT, Aso H, Hagino A \& Obara Y 2005 Growth hormone acts on the synthesis and secretion of alpha-casein in bovine mammary epithelial cells. Journal of Dairy Research 72 264-270

Svenersten-Sjaunja K \& Olsson K 2005 Endocrinology of milk production. Domestic Animal Endocrinology 29 241-258

Zhou Y, Akers RM \& Jiang H 2008 Growth hormone can induce expression of four major milk protein genes in transfected MAC-T cells. Journal of Dairy Science 91 100-108 